\title{
STUDI AKTIVITAS NELAYAN KAMAL MUARA DENGAN ADANYA REKLAMASI
}

\author{
${ }^{1)}$ Urip Rahmani \\ ${ }^{1)}$ Fakultas Perikanan dan Ilmu Kelautan Universitas Satya Negara Indonesia \\ Jln. Arteri Pondok Indah n0.11 Jakarta 12240 \\ E-mail: tufikan@yahoo.com
}

\section{PENDAHULUAN}

Kebijakan reklamasi bagi kota-kota pantai di dunia merupakan keniscayaan. Sebagai contoh, Belanda yang negerinya berada di bawah permukaan laut, reklamasi dilakukan untuk menanggulangi masuknya air laut ke daratan. Contoh lain adalah New York dan Hongkong yang secara bertahap melakukan reklamasi perairan pantainya sehingga menjadi kota yang indah dan menjadi destinasi wisata dunia.

Provinsi DKI Jakarta yang merupakan kota pantai, memiliki anggapan sama dimana reklamasi menjadi kemestian yang harus dilakukan, ketimbang wilayah perairan makin tergerus oleh abrasi air laut. Salah satu contoh keberhasilan reklamasi adalah terbangunnya kawasan Ancol Jakarta Utara yang sebelum reklamasi merupakan rawa. Kawasan ini senantiasa tergerus oleh abrasi. PT Pembangunan Jaya yang mendapat tugas tahun 1960 untuk mengembangkan kawasan Ancol, melakukan reklamasi dengan cara menguruk rawa dan memecah ombak dan mesedimentasikan pasir laut dalam sebuah wadah yang disiapkan dipinggir pantai. Perlahan tapi pasti wilayah daratan Ancol berkembang sebagaimana terlihat saat ini, dan menjadi destinasi wisdom dan wisman.

Proyek reklamasi pesisir Kota Jakarta dimaksudkan untuk menambah ruang pembangunan Jakarta. Selain itu, reklamasi ini bertujuan untuk mencegah pengikisan daratan Jakarta oleh air laut, serta membangun beberapa fasilitas kota lainnya. Kawasan selatan Jakarta sudah tidak mungkin dikembangkan karena fungsinya sebagai daerah konservasi. Ditambah lagi dengan kondisi wilayah timur dan barat Kota Jakarta yang sudah telanjur padat penduduk karena sejak 1985 pengembangan wilayah Jakarta sudah diarahkan ke timur dan barat. Selain itu reklamasi pantai utara Jakarta juga bertujuan untuk menata kembali kawasan Pantura dengan cara membangun kawasan pantai dan menjadikan Jakarta sebagai kota pantai (waterfront city).

Namun demikian dari segi lingkungan hidup dapat dibilang bahwa Reklamasi akan merubah wilayah pesisir Jakarta. Ekosistem bawah laut menerima dampak dari proses reklamasi yang dilakukan. Nelayan harus menempuh jarak lebih jauh untuk mendapatkan ikan. Dampak yang timbul dari proyek reklamasi ini adalah terkait dengan beberapa aspek sosial ekonomi penduduk yang berada di dekat/sekitarkawasan reklamasi. Penelitian ini bertujuan untuk mengetahui permasalahan yang dihadapi nelayan serta aktivitas nelayan sebelum dan selama berlangsungnya reklamasi, bagaimana kontribusi yang sebaiknya dilakukan oleh perusahaan yang melakukan reklamasi. Lokasi penelitian di wilayah Kamal Muara.

\section{METODE PENELITIAN}

Penelitian dilaksanakan pada bulan November 2016 di kawasan Kelurahan Kamal Muara Jakarta Utara RW 01 dan RW 04 yang menjadi kawasan nelayan di Kamal Muara. Perusahaan yang melakukan reklamasi adalah PT Kapuk Naga Indah. Data penelitian adalah data primer. Data primer diperoleh dari hasil wawancara berdasarkan kuesioner. Metode penelitianini bersifat kuantitatif-deskriptif-komparatif dan kualitatif dimana akan memberikan gambaran utuh atas semua data yang diperoleh untuk mengetahui permasalahan yang dihadapi nelayan serta aktivitas nelayan sebelum dan selama berlangsungnya reklamasi. Untuk dapat memperoleh ketajaman hasil penelitian, dilakukan wawancara mendalam berdasarkan panduan wawancara yang dikembangkan secara sistematis berdasarkan wawancara terhadap informan penelitian. Obyek penelitian adalah kondisi wilayah perairan pantai Kamal dan alat tangkap ikan, produksi perikanan para nelayan tradisional, serta persepsi masyarakat terhadap reklamasi.Analisis terhadap jumlah nelayan, jumlah armada, jumlah produksi dilakukan secara deskriptif. Deskripsi ini juga sekaligus mengkomparasikan kondisi eksisting saat reklamasi berjalan 
dengan kondisi eksisting sebelum reklamasi. Hasil ini diharapkan memberikan gambaran utuh terhadap keberadaan reklamasi.

Analisis kualitatif dilakukan selama pengumpulan data dengan snow-ball analysis, dimana hasil wawancara terhadap seorang atau beberapa orang orang dievaluasi dan selanjutnya dimodifikasi sehingga mampu menggali semua informasi yang diperlukan. Melalui subyek Kajianini, peneliti meminta saran siapa subyek Kajianselanjutnya. Dengan cara yang sama dilakukan wawancara terhadap subyek Kajianbaru berdasarkan hasil modifikasi panduan wawancara. Selanjutnya jika jawaban responden dipandang cukup, dengan paramater konsistensinya jawaban reponden, maka responden berikutnya adalah para tokoh masyarakat setempat. Apabila jawaban responden belum mengarah pada tujuan penelitian, panduan wawancara dimodifikasi kembali yang kemudian menjadi panduan wawancara dari responden baru. Kompilasi atas semua jawaban responden akan menjadi bahan panduan wawancara terhadap tokoh masyarakat, pimpinan instansi pemerintah daerah dan pimpinan instansi sektor perikanan.Khusus untuk persepsi masyarakat terhadap reklamasi dilakukan analisis deskriptif dan selanjutnya diperdalam melalui wawancara dan dianalisis secara kualitatif.

\section{HASIL DAN PEMBAHASAN}

\section{Hasil}

Responden penelitian terdiri dari 31 orang warga RW 01 dan RW 04 Kelurahan Kamal Muara. Sebelum menyajikan tanggapan responden tentang aktivitas mereka mencari ikan selama reklamasi dan sebelum reklamasi, disajikan terlebih dahulu keberadaan penduduk di kawasan ini, klasifikasi nelayan dan alat tangkapnya serta usaha perikanan yang sudah berjalan. Selain itu disajikan pula gambaran tentang perusahaan yang memiliki hak membangun pulau reklamasi yaitu PT Kapuk Naga Indah di dekat kawasan perairan pantai Kamal Muara.

a. Komposisi Penduduk Kamal Muara

Dilihat banyaknya penduduk menurut RW, terbanyak di RW 04 sebanyak 2.742 jiwa. Jumlah penduduk tiap RW disajikan padaTabel1.

Tabel1.BanyaknyaPendudukdi Menurut RWKelurahan KamalMuaraTahun 2015

\begin{tabular}{|l|l|r|r|r|r|r|r|r|}
\hline \multirow{2}{*}{ No. } & \multirow{2}{*}{ RW } & \multicolumn{3}{|c|}{ WNI } & \multicolumn{3}{|c|}{ WNA } & Total \\
\cline { 3 - 8 } & & Laki & \multicolumn{1}{c|}{ Pr } & Jumlah & Laki & Pr & Jumlah & \\
\hline 1 & 01 & 2.330 & 2.029 & 4.359 & - & - & - & 4.359 \\
\hline 2 & 02 & 720 & 667 & 1.387 & - & - & - & 1.387 \\
\hline 3 & 03 & 996 & 1.051 & 2.047 & 5 & 3 & 8 & 2.055 \\
\hline 4 & 04 & 1.369 & 1.373 & 2.742 & - & - & - & 2.742 \\
\hline 5 & 05 & 734 & 774 & 1.508 & 8 & 4 & 12 & 1.520 \\
\hline 6 & 06 & 693 & 688 & 1.381 & 6 & 5 & 11 & 1.392 \\
\hline & Jumlah & 6.842 & 6.582 & 13.424 & 19 & 12 & 31 & 13.455 \\
\hline
\end{tabular}

Sumber:MonografiKelurahan Kamal MuaraTahun 2015

Data mengenai komposisi penduduk di Kelurahan Kamal Muara menurut menurut kelompok umur disajikan pada Tabel2danGambar 1.

Tabel2.Komposisi Penduduk Menurut Kelompok Umurdi Kelurahan Kamal MuaraTahun 2014

\begin{tabular}{|c|r|r|r|r|}
\hline Kelompok Umur & Laki-laki (Jiwa) & Perempuan (Jiwa) & Jumlah (Jiwa) & Persentase (\%) \\
\hline $0-4$ & 550 & 581 & 1131 & 8,37 \\
\hline $5-9$ & 583 & 593 & 1176 & 8,71 \\
\hline $10-14$ & 720 & 593 & 1313 & 9,72 \\
\hline
\end{tabular}




\begin{tabular}{|c|r|r|r|r|}
\hline Kelompok Umur & Laki-laki (Jiwa) & Perempuan (Jiwa) & Jumlah (Jiwa) & Persentase (\%) \\
\hline $15-19$ & 619 & 561 & 1180 & 8,73 \\
\hline $20-24$ & 639 & 625 & 1264 & 9,36 \\
\hline $25-29$ & 640 & 588 & 1228 & 9,09 \\
\hline $30-34$ & 563 & 603 & 1166 & 8,63 \\
\hline $35-39$ & 576 & 548 & 1124 & 8,32 \\
\hline $40-44$ & 540 & 465 & 1005 & 7,44 \\
\hline $45-49$ & 422 & 469 & 891 & 6,60 \\
\hline $50-54$ & 411 & 356 & 767 & 5,68 \\
\hline $55-59$ & 280 & 336 & 616 & 4,56 \\
\hline $60-64$ & 132 & 133 & 265 & 1,96 \\
\hline $65-69$ & 90 & 80 & 170 & 1,26 \\
\hline $70-74$ & 54 & 63 & 117 & 0,87 \\
\hline $75+$ & 42 & 54 & 96 & 0,71 \\
\hline Total & 6.861 & 6.648 & 13.509 & 100,00 \\
\hline
\end{tabular}

Sumber:MonografiKelurahan Kamal MuaraTahun, 2015

Berdasarkan tabel di atas terlihat bahwa jumlah penduduk paling banyak dijumpai pada kelompok umur 10 - 14 tahun sebanyak 1.313 jiwa $(9,72 \%)$. Usia yang dikatakan masih inproduktif antara $0-14$ tahun berjumlah 3.620 jiwa (26,80\%), usia produktif antara 15-64 tahun berjumlah 9.506 jiwa $(70,37 \%)$ dan yang dikatakan non-produktif usia 65 tahun ke atas berjumlah 383 jiwa $(2,84 \%)$. Hasil perhitungan diketahui bahwa Rasio Beban Ketergantungan (depedency ratio) penduduk sebesar 42,11\%, yang jikadibulatkanmenjadi42. Ini berarti bahwa setiap seratus penduduk usia produktif di Kelurahan Kamal Muara menanggung 42 jiwa penduduk in-produktif dan non produktif.

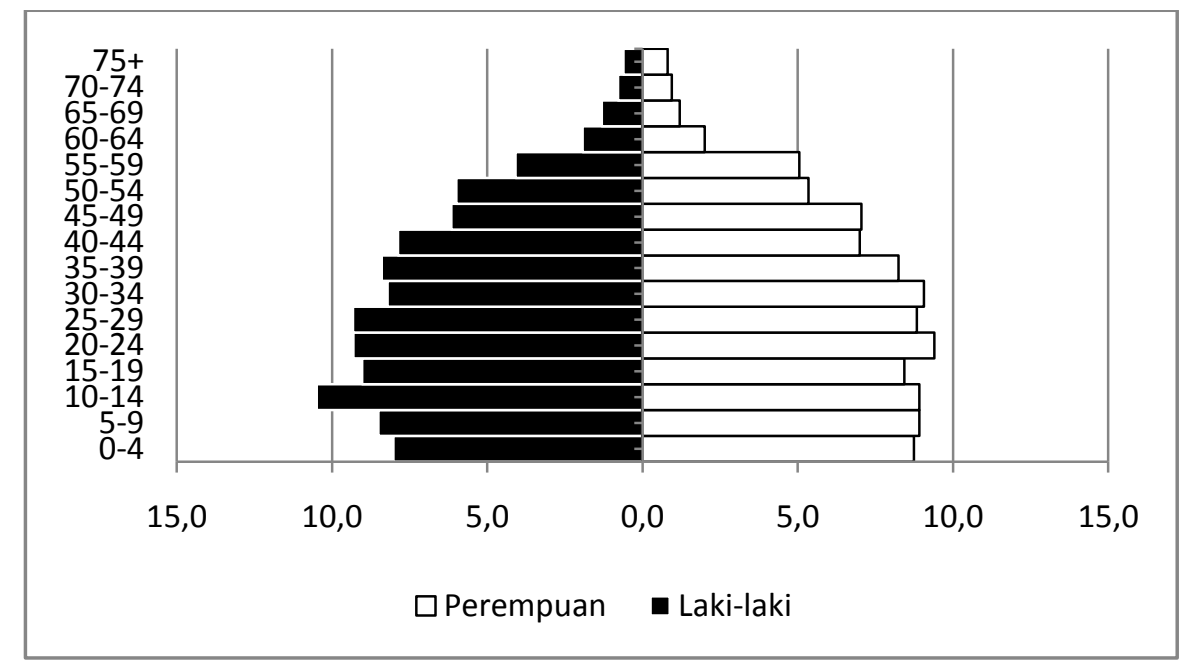

Gambar 1.Piramida Penduduk Kelurahan Kamal Muara Tahun 2015

b. Kegiatan Perikanan

Kegiatanperikanan di Kamal Muarapadaumumnyadilakukanone day fishing. Sebagian besar daerah tangkapan ikan (fishing ground)padaperairansekitar Kamal MuarasepertiPulauDamar atau 1-3 km dari perairan Kamal Muara.Sedangkan alat tangkap bagan apung, daerah tangkapannya di perairan Pulau Bira, Kepulauan Seribu.

\section{b.1. Nelayan}

Nelayan adalah orang yang melakukan penangkapan ikan. Pada kegiatan penangkapan ikan, jumlah nelayan yang melakukan kegiatan penangkapan ikan yang tercatat di Kelurahan Kamal Muara 2015 
sebanya1.060 orang. Untuk nelayan Sero yang tadinya berjumlah 200 orang menjadi 100 orang dan banyak yang beralih profesi menjadi tukang ojek, membuka warung, mekanik bengkel dan lainlain.Saatinijumlahnelayanjaringtongkolsebanyak 7 perahu (RW 01).Selebihnyanelayanbertempattinggal di RW 04, yaituBaganTancap sebanyak 70 orang, BaganApung 7 orang, Sero100, KerangHijauApung>100 Selain beraktivitas secara mandiri, terdapat juga aktivitas Kelompok Usaha Bersama (KUB) dimanasetiap KUB beranggotakan 15-20 nelayan.

\section{b.2.Alat Penangkapan Ikan}

Alatpenangkapanikan di KelurahanKamalMuaraada beberapa macam yaitu pancing, jaring, bubu, sondong dan sero serta bagan apung.

1) Alat tangkap pancing digunakan untuk menangkap ikan di sekitar Pulau Damar atau Kepulauan Seribu dan bukan di sekitar perairan pantai yang memang sudah tidak ada ikannya. Demikian pula untuk alat tangkap sondong.

2) Khusus untuk budidaya kerang hijau, saat ini digunakan tehnik budidaya kerang hijau apung dimana, tidak lagi ditanam di dasar laut tapi digunakan tambang yang diapungkan. Kawasan budidya kerang hijau tersebar cukup banyak di sekitar perairan pantai Kamal Muara.

3) Sero adalah alat tangkap ikan yang tidak diperkenankan berada di sekitar lokasi reklamasi. Oleh sebab itu nelayan membuat Sero di luar kawasan pantai Kamal Muara, yaitu di sekitar Pantai Dadap yang termasuk wilayah Kabupaten Tangerang.

4) Bagan apung sebagai alat tangkap tidak berada di sekitar perairan, tapi berada di kawasan Kepulauan Seribu, baik itu Pulau Onrust, Pulau Damar, Pulau Bidadari yang relatif tidak jauh dari Kamal Muara.

\section{b.4.Jenis nelayan yang ada}

Saat ini nelayan yang ada di Kamal Muara dibedakan atas:

1) Nelayan Sondong yang mencari ikan dengan menggunakan Sondong sebagai alat tangkapnya

2) Nelayan Sero. Bisa merupakan juragan pemilik Sero atau pekerja yang mengambil ikan dari Sero yang ditanam.

3) Nelayan Pancing adalah nelayan yang menggunakan pancing sebagai alat penangkapannya

4) Ternak Kerang Hijau adalah petaniikanyang bergerak di sektor budidaya kerang hijau.Yang sebagian sudah mengubah alattangkapnya menjadi ternak kerang hijau apung.

5) Nelayan Bagan Apung, pada umumnya adalah nelayan pekerja yang mengambil ikan dari Bagan Apung yang ada di kawasan Kepulauan Seribu lalu menjualnya ke TPI Kamal Muara.

6) Nelayan Wisata adalah nelayan yang melayani sewa kapal/perahu untuk pulang dan pergi pengunjung dari Kamal Muara ke Kepulauan Seribu terdekat, seperti Pulau Onrust. Nelayan ini juga berprofesi sebagai nelayan yang melayani transportasi ke dan dari wilayah Kepulauan Seribu, baik sewa ataupun reguler.

\section{b.5. Usaha Perikanan Tangkap}

Kegiatan usaha penangkapan ikan di KelurahanKamalMuaradilakukan dengan menggunakan alat tangkap pancing, bagan apung dan jaring. Seluruh hasil dari usaha penangkapan ikan dilakukan untuk meningkatkan kegiatan ekonomi atau dengan kata lain untuk dijual di TPI Kamal Muara.

Daerah tangkapan ikan (fishing ground) sebagian besar masih dilakukan di sekitar perairan dekat pantai Kamal Muara, dengan jarak sekitar 3 mil dari pantai dengan mesin Yamaha 10 PK. Pada umumya kegiatan penangkapan dilakukan sepanjang tahun, baik musim timur maupun musim barat, hanya saja hasil yang didapatkan berbeda antar tiap musim tersebut.Status kepemilikan peralatan dalam aktivitas penangkapan tersebut dominan adalah milik sendiri.

\section{b.5.1. KerangHijauApung}

Penggantiternakkeranghijaudigunakanalattangkapkeranghijauapung, sehinggabisaberpindahpindah.Perhitungan modal pembuatan budidaya kerang hijau apung. 
- bambu 60 batang

- drum 15

- tali $20 \mathrm{~kg}$ (untuk pengikat drum)

- tali putih $1 \mathrm{~kg}$ (untuk bibit kerang)

- patok jangkar

- tali patok $11 \mathrm{~kg}$
( 60 batang x $40.000=\operatorname{Rp} 2.400 .000)$

$(15$ drum $x 165.000=\operatorname{Rp} 2.475 .000)$

$(20 \times 35.000=\operatorname{Rp} 700.000)$

$(1 \times 15.000=\operatorname{Rp} 15.000)$

$(\operatorname{Rp} 2.500 .000)$

$(11 \times 40.000=\operatorname{Rp} 440.000)$

Harga kerang dijual dalam perember, 1 ember $( \pm 11 \mathrm{~kg})$ dihargai $\mathrm{Rp} 35.000$. Panen biasanya setiap 5-6 bulan sekali, sesudah adanya reklamasi. Sebelum adanya reklamasi hanya membutuhkan waktu 4 bulan saja kerang bisa panen.Dalam 5 bulan bisa panen 800-1000 ember.

\section{b.5.2. Alat tangkap sondong}

Alat tangkap Sondong merupakan pengganti alat Sero.Sero di lokasi Kamal Muara sudah tidak diperkenankan dan semua Sero sebelum reklamasi sudah diberikan kompensasi sesuai kesepakatan bersama antara pemilik dengan pengelola reklamasi. Perhitungan usaha alat tangkap sondong sebagai berikut:

- Tali Tambang 1 Gulung (50m)

$=\operatorname{Rp} 35.000$

- Jaring 10 M (10 X 6.000)

- Bambu 2 Batang X 35.000

- Harga Kapal

- Biaya Solar 10-15 liter

- Biaya Konsumsi

$=\operatorname{Rp} 60.000$

$=\operatorname{Rp} 70.000$

$=\mathrm{Rp} 10 \mathrm{Jt}$

Hasil tangkap :

- Udang $3 \mathrm{Kg}$

- Rebon $20 \mathrm{Kg}$

- Ikan Ruca

- Cumi-Cumi

Hasil nelayan sebelum adanya reklamsi sangat dirasakan berbeda, dulu hasil tangkap sangat banyak untuk ikan yang didapat, setelah ada reklamasi laut mulai tercemar, bau dan kotor sehingga ikanikan berkurangsehingga pendapatan nelayan sangat berkurang. Alat tangkap sondong ini salah satunya menjadi tambahan pencarian nelayan untuk mendapatkan ikan yang lebih baik. Walaupun biaya oprasionalnya lebih besar karena penggunaan alat tangkap sondong ini menggunakan solar yang lebih banyak.

\section{b.5.3. Usaha Perikanan Bagan Apung}

Alat tangkap bagan apung untuk menangkap teriataucumi-cumi. Alat tangkap tersebut dioperasikan pada malam hari. Teknik pengoperasian bagan ini dengan cara menurunkan jaring, setelah sekitar 1-2 jam, kemudian jaring diangkat. Hasiltangkapandiambil dan ditempatkan ke wadah. Setelah itu, jarring diturunkan kembali. Bagan ini menggunakan lampu sebanyak 6-8 Buah, 100 Watt. Nelayan berangkat sekitar jam 15.00 ke fishing ground di sekitar KepulauanSeribudengan lama perjalanan sekitar 2-3 jam dan kembali lagi ke landing base di TPI Kamal Muara pada pagi hari (one day fishing). Fishing ground nelayan di sekitar PulauBira, KepulauanSeribu. Perendaman jaring membutuhkan waktu sekitar 1-2 jam setelah jarring diturunkan. Dalam semalam penurunan dan penarikan jarring dilakukan sebnayak 5 kali. Nelayan kembali ke fihsing base pada pagi hari (sekitar pukul 04.00)

Modal investasi yang harus dikeluarkan untuk membeli 1 (satu) paket lengkap terdiri dari perahu bagan, mesin dan alat tangkap lengkap yang baru sekitar Rp 150 juta. Ukuran kapal 3 GT.

Hasil tangkapan bekisar antara $100 \mathrm{~kg}$ sampai 10 ton per tripnya. Hasil tangkapan adalah cumi-cumi. Harga jual cumi-cumi bervariasi Rp 10.000 - Rp 15.000/kg. Penerimaan yang diperoleh nelayan per tripnya (dalam satu malam) bervariasi antara Rp 1 juta sampai dengan Rp 100 juta. Setelah dipotong biaya operasional antara Rp 400.000 - Rp 500.000, maka diperoleh pendapatan usaha antara Rp 40.000 - Rp 310.000.

Pada umumnya di sektor perikanan menggunakan sistem bagi hasil. Hasil tangkapan tersebut dibagi 2 dengan rincian 50\% pemilik kapal dan 50\% ABK. Nelayan Pandega (ABK/buruh nelayan) memperoleh 
pendapatan antara Rp 100.000 sampai dengan Rp 1.000 .000 per trip. Pendapatan nelayan bisa lebih banyak pada saat musim cumi, namun juga kadang-kadang tidak memperoleh pendapatan, pada saat bukan musim cumi. Jumlah ABK pada operasi penagkapan ini antara $5-6$ orang. Nelayan libur setiap malam jumat dan bulan terang (antara tanggal 12-17 bulan Jawa). Rata-rata dalam 1 bulan melaut sebanyak 20 kali.

\section{c. Kondisi Terkini Komunitas Nelayan Kamal Muara}

Secara umum wilayah Kamal Muara yang persis berada di pantai perairan Kamal Muara, RW 04 dan RW 01. Setiap terjadi pasang laut, air pasang akan membanjiri wilayah. Semua sampah baik itu plastik, kayu, cangkang kerang, besi, kertas, botol minum gelas dan sampah rumah tangga dll. merupakan benda-benda yang pasti ada pasca banjir air pasang dan tidak dibersihkan kecuali yang ada di jalan-jalan dan terakumulasi di bawah rumah panggung atau bagian yang lebih rendah dari wilayah daratan. Sampah yang berada di bawah rumah panggung terakumulasi. Sedangkan saluran air berupa got di kawasan ini tertutup. Sedangkan kondisi jalan yang ada dalam kondisi sangat baik. Sudah berupa beton dan cukup mengantisipasi banjir yang disebabkan air pasang. Jalan beton ditinggikan berkali-kali dari badan jalan sebelumnya. Peninggian ini ini merupakan salah satu CSR PT KNI dan sudah berlangsung selama reklamasi berjalan

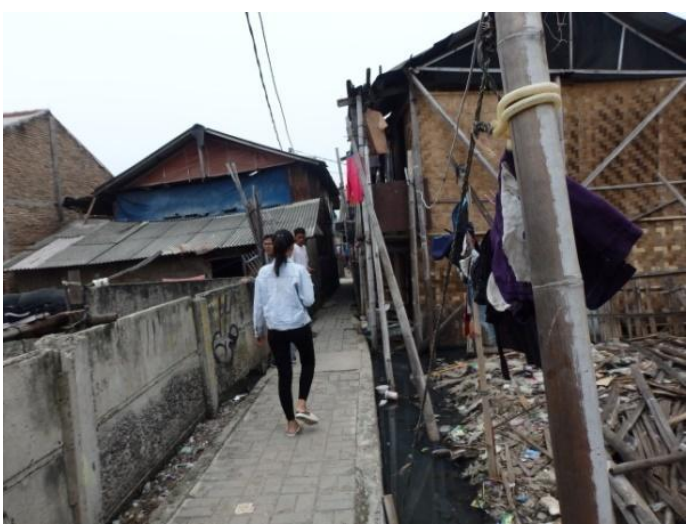

. Gambar 2.

Saluran Air dan Tanah RendahyangPenuhSampah

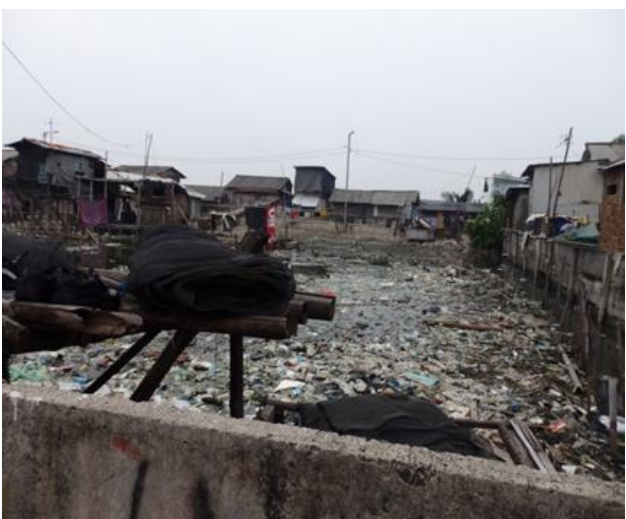

Gambar 3

TimbulanSampah di

KawasanRendahyangBelum Ada Bangunan

\section{d. Kondisi Wilayah Perairan Pantai di Kamal Muara}

Perairan pantai Kamal Muara saat ini bukan berupa pasir tapi berupa beton berongga yang berbentuk U ditempatkan terbalik dan berperan sebagai dam pencegah air pasang. Kawasan Kamal Muara yang ada sesungguhnya hasil akumulasi erosi air laut, sedangkan posisi Kamal Muara sebelum terkena erosi berada di kawasan Pulau Reklamasi. Kondisi wilayah perairan relatif kumuh, berminyak dan berwarna hitam. Kumuhnya perairan ini karena banyak nya sampah plastik, kain, kertas, kayu, juga bambu. Tampak berminyak disebabkan adanya oknum nelayan yang kadang membuang oli bekas di wilayah perairan pantai. Warna hitam yang muncul merupakan akumulasi dari sampah yang ada dan disertai oleh limbah pabrik yang dialirkan ke Kali Kamal yang bermuara ke perairan pantai Kamal Muara.

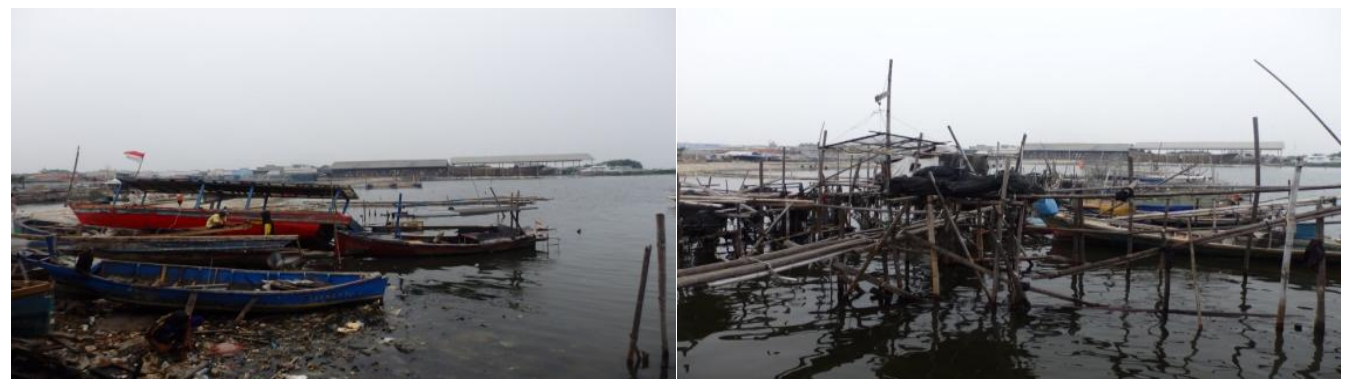

Gambar 4. Kondisi Perairan Pantai Kamal Muara 


\section{e. PT Kapuk Naga Indah}

Di dalam Peraturan Daerah Provinsi DKI Jakarta Nomor 1 Tahun 2012 tentang Rencana Tata uang Wilayah Provinsi DKI Jakarta Tahun 2030, Kawasan Pantura Jakarta ditetapkan sebagai Kawasan Strategis untuk kepentingan ekonomi, lingkungan dan sosial budaya. Pada pasal 101 dimuat arahan Kawasan Strategis Pantura Jakarta sebagai berikut:

1) Kawasan Strategis Pantura mencakup pengembangan areal reklamasi dan kawasan daratan pantai dilakukan secara terpadu yang bersama-sama ditetapkan sebagai satu kawasan perencanaan.

2) Pelaksanaan reklamasi, harus memperhatikan kepentingan lingkungan, kepentingan pelabuhan, kepentingan kawasan berhutan bakau, kepentingan nelayan, dampak terhadap banjir rob dan kenaikan permukaan laut serta sungai, kepentingan dan fungsi lain yang ada di Kawasan Pantura.

Pada pasal 102 dinyatakan bahwa:

1) Penyelenggaraan reklamasi Pantura, diarahkan bagi terwujudnya lahan hasil reklamasi siap bangun dan pemanfaatannya sesuai dengan tata ruang yang terpadu dengan penataan kembali kawasan daratan Pantura.

2) Penataan kembali kawasan daratan Pantura, diarahkan bagi tercapainya penataan ruang yang berhasil guna dan berdaya guna, peningkatan kualitas lingkungan dan perumahan, pelestarian bangunan bersejarah, kelancaran lalu lintas, dan peningkatan fungsi sistem pengendalian banjir baik itu banjir rob dan kenaikan muka laut/sungai.

3) Penyelenggaraan reklamasi serta pengelolaan tanah hasil reklamasi dan penataan kembali kawasan daratan Pantura, dilaksanakan secara terpadu melalui kerjasama usaha yang saling menguntungkan antara Pemerintah Daerah, masyarakat dan dunia usaha.

Bersamaan dengan pemantapan berbagai instrument perencanaan dan pembangunan Kawasan Pantura, Pemerintah Provinsi DKI Jakarta telah mengikat kerjasama dengan beberapa mitra usaha. Pada bulan Juli 1997, Pemda DKI Jakarta telah menandatangani Perjanjian Kerja Sama (Nomor 162 Tahun 1997 dan Nomor 094/KNI-SP/VII/97 tanggal 28 Juli 1997) Pengembangan Penyelengaraan Reklamasi Pada Areal Blok I dan IV Di Sub Kawasan Barat dengan pihak PT. Kapuk Naga Indah. Atas dasar naskah perjanjian kerjasama tersebut PT. Kapuk Naga Indah melakukan berbagai kajian perencanaan, baik kajian rencana tata ruang maupun kajian rencana sarana dan prasarana lingkungan dalam kajian general design. Krisis ekonomi yang menerpa Indonesia dan berbagai negara mengakibatkan terhentinya kegiatan pembangunan fisik terutama pembangunan di bidang properti

\section{f. Persepsi Masyarakat}

Dari semua responden, terdapat 9 orang belum berkeluarga dan 21 orang sudah berkeluarga, dan 1 orang duda. Rata-rata jumlah jiwa dari rumah tangga responden yang berkeluarga sebanyak 2,2 jiwa, dimana yang tertinggi 7 jiwa dan terendah 3 jiwa. Semua responden telah memiliki rumah sendiri, kecuali responden yang belum berkeluarga menyebutkan bertempat tinggal di rumah yang milik keluarga dengan kondisi rumah yang permanen sebanyak 6 buah dan 12 buah semi permanen dengan luas rumah berkisar $50 \mathrm{~m}^{2}-172 \mathrm{~m}^{2}$.

Berdasarkan data di atas, dapat disebut bahwa responden merupakan penduduk yang tidak dapat disebut miskin. Secara lahiriah mereka memiliki rumah sendiri, baik itu permanen ataupun semi permanen, dimana masing-masing anggota keluarga minimal memiliki ruang lebih dari $8 \mathrm{~m}^{2}$ (dengan cara membagi luas rumah dengan jumlah jiwa dalam rumah tangga). Tidak miskinnya responden terlihat dari alat penerangan yang ada berupa listrik, selain itu terdapatnya barang elektronik baik TV (30 orang), Kulkas (20 orang), Hand-Phone (30 orang) ataupun mesin cuci (17 orang). Data juga memperlihatkan bahwa 25 orang responden memiliki sepeda motor yang juga memperlihatkan para responden tidak masuk dalam kategori miskin.

Namun berdasarkan penghasilan yang mereka terima, paling kecil 500 ribu dan paling besar 6 juta, tampak bahwa kategori kemiskinan terpenuhi. Penghasilan nelayan yang tidak menentu atau tidak dapat dipastikan menyebabkan munculnya data reponden seperti ini. Pada saat berpenghasilan besar, maka setelah kebutuhan primer terpenuhi, maka kebutuhan sekunder diadakan seperti barang elektronik TV, 
HP, Mesin Cuci serta sepeda motor. Sedangkan untuk kebutuhan pendidikan anak sudah tersedia Kartu Jakarta Pintar (KJP), dan kesehatan sudah tercukupi oleh Kartu Jakarta Sehat (KJS).

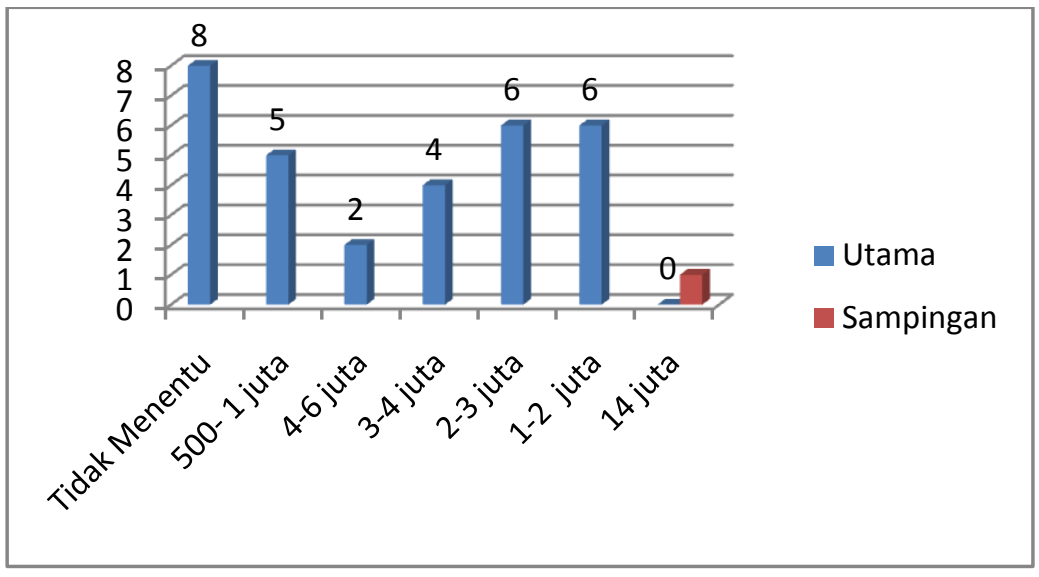

Gambar 5. Tingkat Penghasilan Responden

Tanggapan responden tentang perubahan kondisi perairan Kamal Muara terhadap perikanan budidaya ditanggapi dengan beragam oleh responden. Gambr 6 menggambarkan keberadaan tanggapan ini.

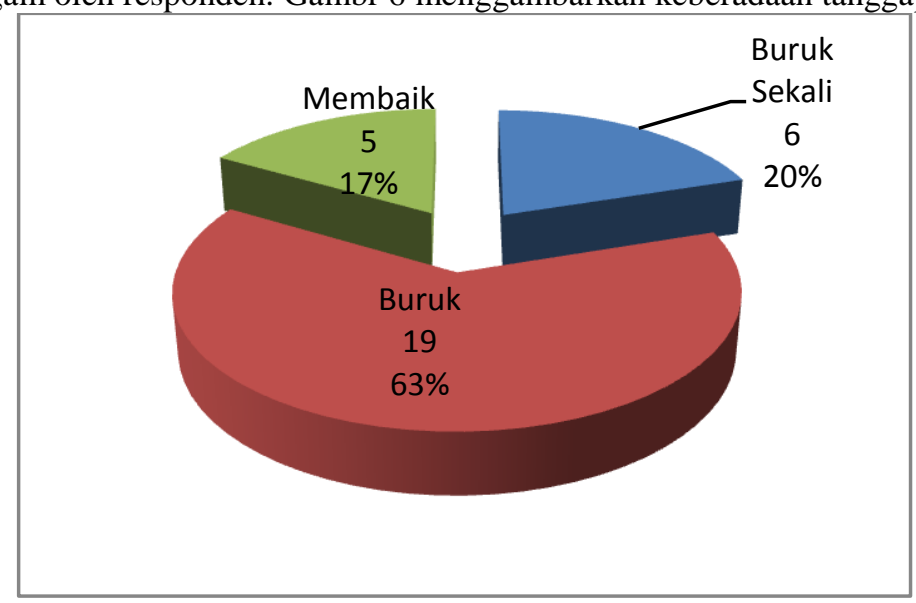

Gambar 6. Tanggapan Responden Terkait Perubahan Kondisi Perairan Terhadap Perikanan Budidaya

Selanjutnya tanggapan responden terkait dengan kondisi perairan yang menurut mereka buruk terhadap perikanan tangkap, ternyata memberikan jawaban yang senada.

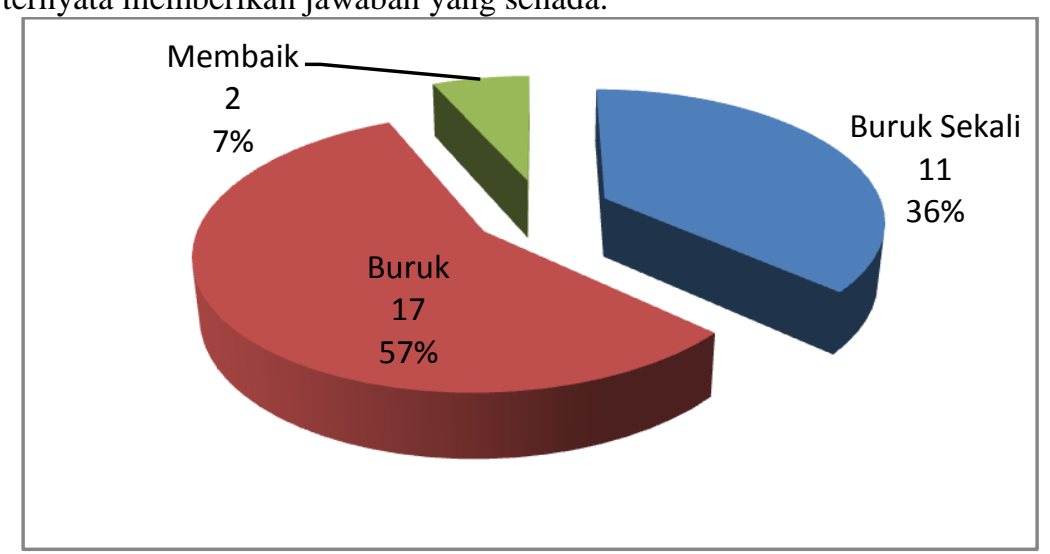

Gambar 7. Tanggapan Responden Terkait Perubahan Kondisi Perairan Terhadap Perikan Tangkap

Responden yang menjawab baik ternyata bersiasat dengan mengambil kesempatan bernelayan di saat nelayan lain tidak bernelayan disebabkan persepsi nelayan lain itu, bernelayan hari ini tidak akan menghasilkan tangkapan yang baik.

Adanya upaya peningkatan kualitas hunian mereka menjadi rumah susun menjadi salah satu bagian menarik yang paling ditunggu masyarakat nelayan. Melulu yang ditanya kapan terlaksananya, apakah mereka dapat tetap beraktivitas sebagai nelayan, apakah tempat tinggal mereka tidak lagi akan kena banjir air laut yang pasang. 
Terkait dengan terbukanya peluang kerja dan kesempatan berusaha saat reklamasi telah selesai dan pembangunan di kawasan reklamasi berjalan, masyarakat nelayan merasa pesimis disebabkan tidak adanya kepastian bagi mereka untuk bisa berkiprah. Ketidakpastian ini disebabkan beberapa hal:

1) Tidak adanya keahlian di sektor yang mungkin akan ditawarkan;

2) Sukar berubah profesi dari nelayan ke profesi lain;

3) Tidak adanya transparansi bentuk tawaran kerja dan kesempatan berusaha sehingga Cuma mereka yang dekat dengan orang-orang tertentu saja yang akan mendapat peluang.

\section{Pembahasan}

Kegiatan reklamasi PT Kapuk Naga Indah berjalan setelah semua aspek legal, aspek lingkungan terpenuhi. Semua berjalan sesuai dengan koridor yang telah ditetapkan. Ganti rugi juga diberikan kepada semua pemilik ternak kerang hijau dan Sero yang berada di perairan Kamal Muara. Kegiatan berjalan sesuai rencana dan dikerjakan secara profesional dan terukur. Semua kemungkinan buruk yang akan terjadi dicegah secara totalitas dengan menggunakan tehnologi terbaik.

Dampak reklamasi yang dirasakan oleh nelayan dibagi dalam 4 kategori utama yaitu dampak terhadap daerah penangkapan ikan, jalur kapal perikanan, kegiatan budidaya perikanan serta sumberdaya ikan (Sampono, 2013). Reklamasi dianggap oleh nelayan Kamal Muara akan memberikan dampak terhadap daerah penangkapan ikan di kawasan pesisir Kamal Muara. Selain itu reklamasi akan memberikan gangguan terhadap jalur perahu nelayan yang akan menuju maupun kembali dari operasi penangkapan ikan. Adanya daratan baru akan menyebabkan perubahan pola alur pelayaran dan jalur keluar masuknya kapal. Hal ini sangat dirasakan oleh nelayan perairan Kamal Muara. Salah satunya adalah kemampuan mereka para nelayan untuk dapat segera berada di lokasi TPI Kamal Muara, yang jam operasionalnya mulai pukul $02.00-08.00$. Makin siang para nelayan merapat ke TPI, makin rendah harga produk ikan yang ditawarkan mereka kepada pembeli ataupun pelele. Selain itu, makin panjangnya jalur pelayaran yang harus ditempuh nelayan akan meningkatkan jumlah penggunaan solar serta biaya operasional selama bernelayan.

Terkait dengan budidaya, untuk kawasan Kamal Muara, budidaya Kerang Hijau tidak mengalami perubahan yang signifikan. Bentuk budidaya saat ini berupa Budidaya Kerang Hijau Apung dan tidak lagi ditanam di dasar laut. Sedangkan untuk sumberdaya ikan dirasakan mengalami penurunan. Sebelum reklamasi berlangsung, masih banyak ikan yang diperoleh nelayan Kamal Muara, baik ikan kecil maupun besar. Saat reklamasi berjalan, ikan besar tidak ada dan pada umumnya yang diperoleh ikan rucah baik dengan pancing maupun jaring. Untuk memperoleh ikan yang lebih besar, harus berada di luar pulau reklamasi.

Reklamasi telah berjalan sejak tahun 2012 hingga moratorium tahun 2016 dan berlanjut kembali setelah dibatalkan oleh pengadilan PTUN. Biaya yang selama ini telah keluar sudah sangat banyak, sementara perencanaan ke depan diproyeksi akan memberikan manfaat bagi masyarakat, pemerintah dan pengusaha. Masyarakat nelayan Kamal Muara sendiri menyikapi kebijakan reklamasi sebagai kebijakan yang sudah secara matang dipikirkan oleh pemerintah sehingga harus didukung oleh mereka. Mereka yang pada galibnya berada di lahan ruang terbuka hijau dan selama aneksasi wilayah ini tanpa ada penindakan dari pemerintah merasa harus mendukung kebijakan reklamasi. Adanya janji dari PT KNI terhadap peningkatan kualitas hunian mereka menjadikan mereka makin mendukung kebijakan ini.

Eksistensi persepsi masyarakat di atas sebenarnya bukan sebuah handicapped, kendala untuk reklamasi ini dapat berjalan sebagaimana perencanaan yang telah ditetapkan. PT KNI sendiri telah berupaya secara terukur menghindari terjadinya ekses negatif terhadap lingkungan dan kehidupan sosial ekonomi masyarakat Kamal Muara. Oleh sebab itu diperlukan sebuah penyikapan serius terhadap persepsi masyarakat dalam bentuk yang mengarah pada pemberdayaan masyarakat dalam rangka merangsang kreativitas berkarya, berusaha dan berinovasi di berbagai sektor ekonomi. Pemberdayaan ini bukan merupakan pemberian cuma-cuma, namun mengarah pada penyediaan pancing bagi kegiatan sosial ekonomi masyarakat.

Semua dampak reklamasi terhadap aktivitas nelayan apabila tidak segera terselesaikan akan menjadi bola salju sehingga makin lama makin membesar dan akan menjadi batu penghalang bagi keberlangsungan reklamasi itu sendiri. Oleh sebab itu perlu divisi khusus untuk menangani semua persoalan dasariah di kawasan Kamal Muara. Divisi ini akan menjadi mata dan telinga tentang Kamal Muara serta berkonsentrasi pada upaya peningkatan kualitas hidup masyarakat nelayan Kamal Muara, selain menjadikan warga di kawasan ini sebagai mitra bagi kawasan reklamasi. 
Secara keseluruhan persepsi masyarakat nelayan terhadap reklamasi pantai utara sangat tidak mendukung. Responden yang merupakan nelayan Kamal Muara, semuanya menyatakan bahwa produksi ikan mereka menurun, tawaran kerja dari PT KNI sedikit, fishing ground menjadi lebih jauh, pengeluaran biaya BBM dan opersional lebih tinggi, penghasilan jauh lebih kecil, sumberdaya perikanan menurun, tidak mau beralih profesi, bentuk alih profesi di luar harapan mereka. Namun persepsi yang terkait dengan berbagai bentuk bantuan dari PT KNI telah sangat dirasakan oleh mereka selama ini.

Selanjutnya agar reklamasi dapat berjalan secara mulus tanpa indikasi negatif baik dari aspek lingkungan maupun aspek sosial ekonomi masyarakat nelayan Kamal Muara, beberapa rekomendasi berikut selayaknya dapat dilakukan:

1) Diperlukan sebuah divisi khusus untuk menangani aspek sosial ekonomi dan budaya masyarakat nelayan Kamal Muara. Divisi ini diharapkan dapat memberikan informasi terkini tentang masyarakat, kebutuhan mereka dan menjadi jembatan komunikasi intensif masyarakat dan PT KNI.

2) Makin jauhnya jalur pelayaran yang harus ditempuh nelayan untuk mencapai fishing ground dan berakibat pada peningkatan penggunaan BBM serta biaya operasional nelayan akan menjadi hambatan bagi keberlangsungan hubungan baik PT KNI dan masyarakat nelayan Kamal Muara. Oleh sebab itu sebaiknya disikapi dengan alternatif sebagai berikut:

a) Penyediaan stasiun BBM (solar) bagi nelayan kawasan Kamal Muara dengan potongan harga tertentu. Distribusi dilakukan tersistem sedemikian rupa sehingga dapat memilah mana yang nelayan dan bukan nelayan. Hanya yang nelayan Kamal Muara yang dapat memanfaatkan subsidi BBM ini. Stasiun terletak di kawasan reklamasi, dan menjadi program CSR PT KNI

b) Memberikan sentuhan tehnologi terhadap mesin kapal/perahu sehingga pemakaian BBM menjadi lebih irit karena bahan bakar solar hanya menjadi pemicu bagi hidupnya mesin dan selanjutnya mesin berjalan dengan menggunakan hidrogen yang dihasilkan oleh air. Tehnologi ini tidak terlalu mahal (5-7 juta rupiah per mesin)

3) Memberikan edukasi atau sosialisasi bagi peningkatan kualitas pemukiman nelayan, sebelum mereka pindah ke kawasan rumah susun yang menjadi program PT KNI.

4) Mengingat bahwa kawasan Kamal Muara memiliki kekhususan yang berbeda dengan kawasan Pantura seperti Muara Angke, Cilincing, Dadap dan Muara Gembong, serta berpotensi untuk dapat dikembangkan sebagai kawasan unggulan di wilayah Kecamatan Penjaringan, maka perlu kiranya untuk direncanakan sebagai Kawasan Wisata Nelayan Muara Angke dengan destinasi wisata kuliner, wisata mangrove, wisata bernelayan, dan kawasan khusus untuk pelatihan dan pendidikan nelayan secara terpadu dan komprehensif. Kawasan ini akan menjadi mitra bagi kawasan Pulau Reklamasi.

5) Dalam rangka melibatkan nelayan sekitar kawasan reklamasi sebagai mitra strategis bagi keberlangsungan pembangunan kawasan reklamasi, sebaiknya PT KNI perlu memikirkan kemungkinan menempatkan hunian nelayan di kawasan pulau reklamasi atau kawasan khusus sebagaimana yang disajikan pada point 4 . Nelayan ini pada gilirannya akan menjadi pendukung kawasan reklamasi secara menyeluruh baik dalam hal produksi ikan yang diperlukan masyarakat di kawasan reklamasi, ataupun cafe/restoran yang menggunakan seafood sebagai kuliner unggulan, serta wisata dan tenaga kerjanya yang dapat dimanfaatkan untuk bekerja di kawasan ini. Di kawasan ini kehidupan nelayan lebih kondusif karena berhadapan dengan laut sebagaimana sebelum reklamasi. Hal ini dimaksudkan sebagai perwujudan dari keinginan agar masyarakat yang dirugikan terlibat dalam pembangunan kawasan reklamasi sehingga sense of belonging nelayan menjadi sangat tinggi.

\section{KESIMPULAN DAN SARAN}

\section{Kesimpulan}

Berdasarkan kajian terhadap aktivitas nelayan di wilayah Kamal Muara sebagaimana disajikan sebelumnya dapat disimpulkan bahwa:

1) Secara umum komunitas nelayan sebelum adanya reklamasi sering mengalami kebanjiran baik saat pasang ataupun saat tingginya curah hujan den menghasilkan kekumuhan berupa banyaknya timbulan sampah, baik kertas, plastik, kaleng, kayu, besi, kaca dan lain-lain serta hancurnya badan jalan. Saat reklamasi berjalan sampai kajian ini berlangsung, banjir dan kekumuhan masih ada namun dengan skala yang jauh lebih rendah, namun badan jalan tetap berfungsi. Hal ini terjadi disebabkan adanya bantuan PT Kapuk Naga Indah terhadap pembangunan infrastruktur jalan dan kantor RW, tempat ibadah dll. 
2) Aktivitas nelayan yang terhenti saat reklamasi berjalan adalah nelayan yang memiliki Bagan Tancap. Sedangkan nelayan Pancing, nelayan Sondong, nelayan Sero, nelayan yang mengambil ikan di Bagan Tancap atau Apung (Pulau Onrust, Pulau Damar, Pulau Bidadari), nelayan wisata, dan petani Kerang Hijau berjalan sebagaimana biasa dan mendaratkan ikannya di TPI Kamal Muara. TPI sendiri hanya sekedar melakukan pencatatan produk yang mendarat, pelelangan dilakukan oleh nelayan.

3) PT Kapuk Naga Indah yang melakukan kegiatan reklamasi pada galibnya sudah bekerja sesuai dengan regulasi yang telah ditetapkan, baik itu dari Pemerintah Pusat, Pemda DKI Jakarta. Keragaan kegiatan teknis reklamasi sangat terukur dan upaya menjaga lingkungan diterapkan sangat ketat sesuai dengan referensi tehnologi terbaru.

\section{Saran}

Reklamasi telah berjalan dan secara hukum dan realitas, sukar untuk menghentikannya, apalagi hasil reklamasi akan menguntungkan banyak pihak, baik untuk pengembang/pemilik maupun Pemda DKI Jakarta. Terkait dengan kajian ini yang terfokus pada aktivitas nelayan, maka kajian ini menyajikan beberapa saran/rekomendasi yang dapat diberikan agar reklamasi ini bagian penting bagi warga Kamal Muara dan menimbulkan sense of belonging warga Kamal Muara terhadap kegiatan reklamasi.

1) Diperlukan sebuah divisi khusus untuk menangani aspek sosial ekonomi dan budaya masyarakat nelayan Kamal Muara. Divisi ini diharapkan dapat memberikan informasi terkini tentang masyarakat, kebutuhan mereka, kebutuhan tenaga kerja PT KNI dan menjadi jembatan komunikasi intensif masyarakat dan PT KNI untuk hal-hal apapun yang menjadi kepentingan warga Kamal Muara dan PT KNI atau sebaliknya.

2) Makin jauhnya jalur pelayaran yang harus ditempuh nelayan untuk mencapai fishing ground (1-3 $\mathrm{km})$ dan berakibat pada peningkatan penggunaan BBM serta biaya operasional nelayan, maka diharapkan adanya bantuan terhadap nelayan/

3) Mengingat bahwa kawasan Kamal Muara memiliki kekhususan yang berbeda dengan kawasan Pantura seperti Muara Angke, Cilincing, Dadap dan Muara Gembong, serta berpotensi untuk dapat dikembangkan sebagai kawasan unggulan di wilayah Kecamatan Penjaringan, maka perlu kiranya untuk direncanakan sebagai Kawasan Wisata Nelayan Kamal Muara dengan destinasi wisata kuliner, wisata mangrove, wisata bernelayan, dan kawasan khusus untuk pelatihan dan pendidikan nelayan secara terpadu dan komprehensif. Kawasan ini akan menjadi mitra bagi kawasan Pulau Reklamasi.

\section{DAFTAR PUSTAKA}

Sampono, N. 2013. Reklamasi Teluk Jakartr dan Kebijakan Perikanan. Ringkasan Disertasi. Sekolah Pascasarjana Institut Pertanian Bogor, Bogor.

Monografi Kelurahan Kamal Muara. 2015. Kelurahan Kamal Muara, Jakarta 